Article

\title{
Financial Eco-Innovation as a Mechanism for Fostering the Development of Sustainable Infrastructure Systems
}

\author{
Juan David González-Ruiz ${ }^{1, *}$, Sergio Botero-Botero ${ }^{2}$ and Eduardo Duque-Grisales ${ }^{3,4}$ \\ 1 Department of Finance, School of Economics and Finance, Universidad EAFIT, Carrera 49 No. 7 Sur-50, \\ Medellín, Colombia \\ 2 Departamento de Ingeniería de la Organización, Facultad de Minas, Universidad Nacional de Colombia, \\ Avenida 80 No. 65-223, Medellín, Colombia; sbotero@unal.edu.co \\ 3 Facultad de Ingeniería, Institución Universitaria Pascual Bravo, Calle 73 No. 73A-226, Medellín, Colombia; \\ e.duque@pascualbravo.edu.co \\ 4 Facultad de Estudios Empresariales y de Mercadeo, Institución Universitaria Esumer, Calle 76 No. 80-126, \\ Medellín, Colombia \\ * Correspondence: jgonza17@eafit.edu.co
}

Received: 20 September 2018; Accepted: 20 November 2018; Published: 28 November 2018

\begin{abstract}
This paper aims to propose a financial framework based on mezzanine-type debt for financing Sustainable Infrastructure Systems (SIS). In our analysis, an exploratory-type methodology based on a post-positivist approach for describing the financial eco-innovation in the sustainable infrastructure context is used and consequently, the essential framework's theory is developed, as well as the characteristics and schemes for its functioning. Moreover, the theoretical foundations of financial eco-innovations are analyzed. It was concluded that researchers could benefit from this framework by acquiring a better knowledge of how a mezzanine-debt type could work together sustainability criteria. This paper is expected to contribute to expanding the existing knowledge and expanding funding knowledge frontiers for SIS, as well as contributes to providing a foundation for new research topics. The originality of the proposed framework is intended to establish new ways in order to close the gap between the development of SIS and financing sources using the incorporation of sustainability criteria in the financing process. Thus, the importance of this work is based on the fact that it can be used as an academic support for producing practical solutions.
\end{abstract}

Keywords: sustainable infrastructure systems; project finance; public-private partnerships; eco-innovation; mezzanine

\section{Introduction}

There is a growing need to develop sustainable infrastructure systems (SIS) that address coverage gaps worldwide and in turn, allow limiting the increase of temperature to no more than two degrees Celsius [1]. In this way, there is an opportunity arises to capitalize private finance on being an integral player in shaping the future green economy and financing infrastructure [2,3]. However, given that climate financing requirements are large and that there is scarcity of public funds and a restricted debt capacity, some countries have not been able to reach their investment goals [3]. Thus, financing mechanisms, which include sustainability criteria for developing a new kind of infrastructure, are required in order to meet both investment and climate changes goals [4].

Indeed, the empirical evidence obtained thus far regarding the positive relation between Public-Private Partnerships (PPPs) and Project Finance (PF) suggest a need for more detailed analysis of the infrastructure financing process [5-10]. 
Since the PPPs and PF approaches are the most essential tools for developing new infrastructure systems [11,12] and there is a recognized need to incorporate sustainability considerations in infrastructure projects delivered PPPs [13], there is an opportunity for using eco-innovative financing strategies, which involves economic, environmental, and social sustainability issues.

In this way, incorporating sustainable financing mechanisms will allow increasing eco-innovative strategies that boost both the Sustainable Development Goals (SDGs) and investment infrastructure goals [2]. These kinds of strategies are characterized by including social, economic, and environmental issues in the financing process. Thus, the research trends in this topic may enable researchers and practitioners to emphasize detailed issues on how PPPs might operate to achieve the SDGs [14].

The development of infrastructure systems requires not only the inclusion of the private sector, the mobilization of financial resources and the development of capital markets, but also the use of financing eco-innovative mechanisms. Given that, this kind of financing mechanism should have a pivotal role in transforming how infrastructure is financed. It allows leading to a reorientation of the investment-financing process towards market mechanisms that promote sustainable development that account for environmental, social, and economic variables in the financing process. As a result, efforts to close the coverage gap by means of developing sustainable infrastructure systems (SIS) should seek to transform how infrastructure is financed. It allows leading to a reorientation of the investment-financing process towards market mechanisms that promote sustainable development.

Additionally, as financial investment decision-makers are increasingly incorporating sustainability criteria, the relatively new concept of sustainable finance, which can be categorized under the umbrella of eco-innovation, is progressively becoming more important in the financing process [15]. The idea of conceptualizing and deepening the relationship between sustainability and finance is also supported by Schumpeter [16]; who argues that finance is vital for technological innovation and economic development.

Thus, in order to establish a stronger relationship between sustainability and finance focused on infrastructure systems, this research also seeks to explain the principles of financing eco-innovative in response to the growing interest of the scientific and business world in this emerging field [17]. However, despite the rapid development of research on these topics and their applications, the knowledge on this intersection is still at a nascent stage. Therefore, it is necessary to encourage research in this field. It provides opportunities for research on the main elements of financing SIS. Therefore, a deeper effort to examine key points of financing eco-innovative in the SIS context is also required.

The realm of the research is infrastructure financing [18]. This area aims at developing scientific proposals leading to practical solutions for the infrastructure industry. In this way, this work draws on both management and engineering sciences with a significant concentration in the infrastructure systems management. Thus, this research has been conducted under the assumption that, due to the increasing development of both social and economic infrastructure systems, it is vital to develop eco-innovative financing schemes that allow for operational viability, an equitable distribution of risks, and greater benefits for stakeholders [11] through sustainable financing schemes. In this regard, Wang et al. [19] reported that construction companies that make emphasis on social items establish a good reputation between internal and external stakeholders. For this reason, construction managers should consider social, as well as economic and environmental items [20].

This study aims at proposing a theoretical framework based on mezzanine-type debt for financing SIS. Mezzanine-type primarily involves debt, but also some equity capital features that occupy an intermediate position between senior debt and common equity shares. For this reason, mezzanine debt is also called quasi-equity [21]. Although mezzanine-type is used in other forms of structured finance, it has not been widely used in PF [10]. This contribution identifies the theoretical foundations of financial eco-innovations, and the relation between PPPs and PF is also analyzed. This study is based on the hypothesis that, there are not any elements that determine the existence of some kind 
of Triple Bottom-Line (TBL) element subordination in the structuring of financing, particularly when paying debt service or transforming debt into shares.

The proposed framework is intended to bring a new insight on how to close the gap between the development of SIS and financing sources. In this way, this study contributes to expanding the existing knowledge and expanding funding knowledge frontiers for SIS by means of PPPs and PF.

Also, in order to establish a stronger relationship between sustainability and finance, this study seeks to explain how to develop the principles of eco-innovative financing in response to the growing interest of the scientific and business world in this emerging field [17]. Consequently, the present study will also improve the understandings of the relationship between sustainability and finance [22,23]. The central limitation of this research is that the framework proposed has not empirically been tested yet. In this case, future research will seek to validate the framework proposed through case studies. In addition, this paper presents potential future research topics derived from the analysis. Thus, this theoretical paper deals with financial eco-innovation as a mechanism for boosting the development of SIS.

In our analysis, an exploratory-type methodology based on a post-positivist approach for describing the financial eco-innovation in the sustainable infrastructure context is used and consequently, the essential framework's theory is developed, as well as the characteristics and schemes for its functioning. Thus, this study addresses a comprehensive, systematic and holistic literature review covering all research papers published in leading journals in the fields related to sustainability, project management, infrastructure systems, and finance. In this way, research papers derived from the bibliographic databases ISI Web of Science (WoS) and Scopus were analyzed to conduct this study. According to Waltman [24], these databases are among the ones with the highest academic research reputation. For having concise results from the databases, combinations based on these keywords are used: Sustainable infrastructure systems, project finance, public-private partnerships, eco-innovation, mezzanine, infrastructure investment, and financial framework.

The paper is organized as follows: After this introduction, which provides a context with the main elements of the study, the theoretical background on financial eco-innovations is presented. Next, the elements of PPPs and PF schemes for developing SIS are presented. Then, the framework proposed is presented followed by the current situation and trends in infrastructure financing, as well as further research topics. Finally, the last section summarizes the conclusions.

\section{Theoretical Background}

In this section, we introduce the most significant contributions to financial eco-innovations, as well as the theoretical basis related to the main barriers and instruments to develop financial eco-innovations and incentives to encourage private participation. In particular, we address finance from an innovation perspective for developing SIS.

Although ongoing debates about sustainability show that an exact meaning of the concept remains ambiguous [13] and that there is not a common agreement on the definition of SIS [25], a holistic definition of the latter, linking the SDGs to the financial attractiveness for investors states that "an infrastructure that integrates environmental, social and governance aspects into a project's planning, building and operating phases while ensuring resilience in the face of climate change or shocks is capable of making the difference: [I]t improves the attractiveness of infrastructure investments by mitigating risks, creating tangible benefits and opportunities as well as reducing emissions and climate risks" [26] (p. 4).

According to several authors, financial innovation emerged to complement traditional financing structures that had already become insufficient to meet the growing need to maintain and restore infrastructure and close the financing gap $[18,27]$. Furthermore, those authors note that sustainable financial innovations are based on the analysis of policies and the integration of various participants. They argue that the financing process includes various activities, including interactions among governments, local agencies, and public-private sectors. Similarly, innovative financing (such as 
securitization, one of the most commonly applied innovations in the 1980s), has been intended to expand the supply of financial instruments to complement traditional sources and meet existing needs [28]. It also provides mechanisms to capitalize projects when traditional sources are unavailable because of high investment risk [29].

An innovative financing instrument is characterized by introducing or improving a product that allows for the creation of new markets and, therefore, attracts new entrants [30]. Besides, financial innovations are defined as any development, combination or modification of financial instruments or any element of the financial system (institution, regulation, or market) [29].

Thus, mechanisms such as PPPs, credit enhancement tools and fixed-income financing instruments (such as bonds) have emerged to complement traditional approaches, such as leaseback, expected revenues and availability-based payment mechanisms [27]. Other approaches categorized as green financial products include eco-leases, climate mortgages, and green lending [6,31,32].

From an economic-financial perspective, the role of innovation is one of the main areas of study for researchers from various disciplines. Nevertheless, theoretical and methodological approaches to understanding eco-innovations remain limited [33], and discussions on these topics are based on the neoclassical tradition, namely, on environmental economics, innovation economics, and ecological economics [17].

Although the definition of eco-innovation has been widely discussed in various disciplines, there is no common definition of the concept in the literature $[34,35]$. At present, due to the multidisciplinary nature of the term, which has led to the use of different terminologies for the same approach or subject [6], eco-innovation is used as a synonym for "green innovation", "sustainable innovation" and "environmental innovation" [35,36]. Table 1 provides the most prominent definitions of these concepts in the literature share elements related to eco-innovative financing.

Table 1. Relations between financial eco-innovation with the most definitions.

\begin{tabular}{cccc}
\hline Author/Element & $\begin{array}{c}\text { Green Financial } \\
\text { Innovation }\end{array}$ & $\begin{array}{c}\text { Creation of a New Market, } \\
\text { Product, Process or Service }\end{array}$ & $\begin{array}{c}\text { Processes of Innovation towards } \\
\text { the Sustainable Development }\end{array}$ \\
\hline$[6]$ & $\mathrm{x}$ & $\mathrm{x}$ & $\mathrm{x}$ \\
{$[5]$} & $\mathrm{x}$ & $\mathrm{x}$ & $\mathrm{x}$ \\
{$[37]$} & $\mathrm{x}$ & $\mathrm{x}$ & $\mathrm{x}$ \\
{$[38]$} & & $\mathrm{x}$ & $\mathrm{x}$ \\
{$[39]$} & $\mathrm{x}$ & $\mathrm{x}$ \\
{$[17]$} & $\mathrm{x}$ & $\mathrm{x}$ \\
{$[40]$} & & & $\mathrm{x}$ \\
\hline 41$]$ & & & \\
\hline
\end{tabular}

In one of the more explicit definition Rennings [37] emphasizes that eco-innovation can be present at a technological, organizational, social, or institutional level in companies or non-profit organizations. Given its interdisciplinary approach, it can be located between economic innovation and environmental economics. However, according to some ethical and responsible investment theorists [42,43] sustainable investments (which involve financial eco-innovations) make it possible to broaden the population of investors beyond traditional investors, who only consider financial criteria in making investment decisions, to include socially responsible investors, who also consider non-financial criteria.

Thus, the availability of sustainable investments will demand inclusion and, therefore, development of socially responsible financial products [23]. This is highlighted by Linnenluecke et al. [44], who note that investments with an environmental component are becoming a trend in empirical research. In response to this, and with the aim of validating the "it pays to be green" hypothesis, a growing empirical literature has demonstrated (using econometric techniques) that strong environmental results are associated with better financial performance [45].

This finding is echoed in an in-depth study that reports that eco-innovative companies generally have higher Returns on Assets (ROA) and Returns on Equity (ROE) [23]. These findings also indicated 
that the ability to innovate in the financial field is relevant for the development of eco-innovations, as it broadens understandings of the implications of financial performance resulting from innovation. The larger a company is, the greater the extent to which the application and development of eco-innovations can reduce its environmental impact while satisfying interest groups [35]. Furthermore, the implementation of green practices by companies can satisfy and maintain financial support from interest groups [46].

In this regard, some authors [47-49] argue that it is necessary to change traditional shareholders' maximization of sustainable value creation as the only viable way forward; likewise, these authors notably described sustainable and financial investment. They found no differences between the two aspects and that both investment types should create social, economic and environmental value. Thus, there has been a call for an adjustment in the traditional financial valuation framework based on the TBL criteria [48]. A call for attracting green resources requires the development of funding mechanisms that expose investors to sustainable infrastructure assets [50]. According to Martens and Carvalho [49] (2016), the most widely applied concept related to sustainable development is known as the TBL, developed by Elkington [51]. It integrates the economic, environmental and social dimensions. The TBL concept suggests that organizations should devote attention not only to their financial behavior, but also to the social and environmental benefits that can be obtained from a project [49]. Thus, when the TBL is used, the economic, social and environmental aspects of a project will be better integrated [49]. Based on the above, it is no longer true that investment decisions are based only on financial returns; instead, they are also based on a combination of economic, social, and environmental issues [52]. Thus, "the efficient placement and management of assets entails the development of investment and financing models that ensure the optimal allocation of funds for achieving the desired social impact while ensuring capital preservation and investors' financial return" [53] (p. 812). Also, investors are expected to capture not only financial value, but also a wide of intangible assets and institutional benefits [54].

Regarding PF schemes, it cannot be guaranteed that the use of these ensures that a project will raise the financial resources for its development [9]. Also, such schemes may not have either operation profitability (measured by the ROA) or equity profitability (measured by ROE). Anyhow, wise investors seek a higher ROE than ROA. Table 2 shows the main contributions on this topic.

From the perspective of generating new business models, the development of SIS offers a relevant setting for conducting new research that interrelates infrastructure, sustainability and finance seeking to close the coverage gap through business models that generate lower environmental impacts (and greater social and economic benefits than do traditional models) [34]. Therefore, the development of new business models and the appearance of green capital sources are considered the most important reasons for companies to turn toward eco-friendly investments [55].

Table 2. Returns on Assets (ROA), Returns on Equity (ROE), and mezzanine-type debt contributions.

\begin{tabular}{|c|c|}
\hline Description & Authors \\
\hline $\begin{array}{l}\text { Based on a theoretical example, he demonstrates that using mezzanine debt as a financing } \\
\text { source, it is possible to improve ROE. }\end{array}$ & [9] \\
\hline $\begin{array}{l}\text { Emphasize that the consequences of better environmental performance should lead to a } \\
\text { better forthcoming financial performance reflected in the ROA and the Operational Cash } \\
\text { Flow, as well as in a higher value of the firm measured by Enterprise Value. Also, they } \\
\text { demonstrated that good environmental performance reduces regulatory risks. Therefore, } \\
\text { this affects directly corporate valuation through a lower discount rate. }\end{array}$ & [45] \\
\hline $\begin{array}{l}\text { Investors may opt for cheaper Capital Expenditures (Capex) in exchange for higher } \\
\text { long-term Operating Expenditures (Opex). As a result, the initial higher costs required to } \\
\text { implement sustainability practices may negatively affect the short-term Return on } \\
\text { Investment (ROI) thereby discouraging decision makers from adopting such methods. }\end{array}$ & [56] \\
\hline
\end{tabular}


Table 2. Cont.

\begin{tabular}{lc}
\hline \multicolumn{1}{c}{ Description } & Authors \\
\hline Green benefits derived from sustainable financing are incorporated in the calculation of the & {$[57]$} \\
WACC. & [58] \\
\hline $\begin{array}{l}\text { He provided a theoretical foundation for amending the discount rates currently used for } \\
\text { project analysis to account for the social and environmental aspects of business operations } \\
\text { and investments. }\end{array}$ & \\
\hline
\end{tabular}

Thus, sustainable innovation can be understood as a process that includes environmental, social, and financial sustainability factors and integrates them into the business development system, generating new business models and forms of organisation. Thus, there is a demand for business models that link value creation with social and ecological consciousness in a balanced way [49].

The importance of innovation in the financing context is based on it enables numerous cities that face difficulties in obtaining financial resources to find options that will facilitate the development of projects that incorporate attractive climatic objectives for investors. In this respect, development banks play a critical role as fund providers to overcome existing monetary barriers [59].

Thus, the development of financial mechanisms represents a means of alleviating financial constraints [41], and therefore, it is important to have policies and regulatory frameworks that will address the financial gap and solve long-term financing problems [60]. Similarly, the debate on climate change and sustainable development have driven research processes to develop eco-innovations capable of reducing carbon emissions and promoting green economic growth [41], as reported [61] in the study on resilient transport infrastructure systems and sustainable economic growth. However, financial barriers, such as imperfect financial markets, scalability, the absence of financial assets and weak regulatory environments have stymied the generation and introduction of eco-innovations into the market [41,62]. Furthermore, "public funds can be used to remove barriers to early entrant investors; some specific tools include tax incentives, foreign exchange liquidity facilities, loan guarantees, and subsidies, technical infrastructure, information provision, and through fiscal tools, such as risk transfers, insurance, and equities" [3] (p. 185). Table 3 summarizes the main barriers.

Table 3. Main barriers and instruments to develop financial innovations.

\begin{tabular}{|c|c|c|}
\hline Barrier & Instrument & Authors \\
\hline Associativity & $\begin{array}{c}\text { Public-Private Partnerships (PPPs) and } \\
\text { Project Finance (PF) }\end{array}$ & {$[41,63,64]$} \\
\hline $\begin{array}{l}\text { Investment in Research and } \\
\text { Development }\end{array}$ & Tax credits & {$[57,65]$} \\
\hline Institutional weakness & Regulation & {$[64]$} \\
\hline Capital market development & $\begin{array}{l}\text { Development of financing mechanisms. } \\
\text { Expand the base of issuers }\end{array}$ & {$[41,62,63,66,67]$} \\
\hline Funding sources & $\begin{array}{l}\text { Private equity funds, Angeles Investors, } \\
\text { Banks, PF, Mezzanine, }\end{array}$ & {$[41,60,63,68-70]$} \\
\hline Early entrant investors & $\begin{array}{l}\text { Tax incentives, foreign exchange liquidity } \\
\text { facilities, loan guarantees, and subsidies, } \\
\text { technical infrastructure and information } \\
\text { provision, and PPPs through fiscal tools, such } \\
\text { as risk transfers, insurance, and equities }\end{array}$ & {$[3,71]$} \\
\hline Attracting sufficient funds & Governmental guarantees, Loan guarantees & {$[3,72]$} \\
\hline
\end{tabular}

Thus, further research is needed to explore how the underlying characteristics of financing processes impact the relationship between companies' sustainable and financial performance [42], as innovation could deliver both financial (based on fiscal incentives) and environmental benefits 
(based on reduced carbon emissions, as well as subsidies, money transfer, loan guarantees or tax credits) for boosting the development of SIS [41,73]. Figure 1 shows the main financial incentives for boosting the development of SIS through private participation

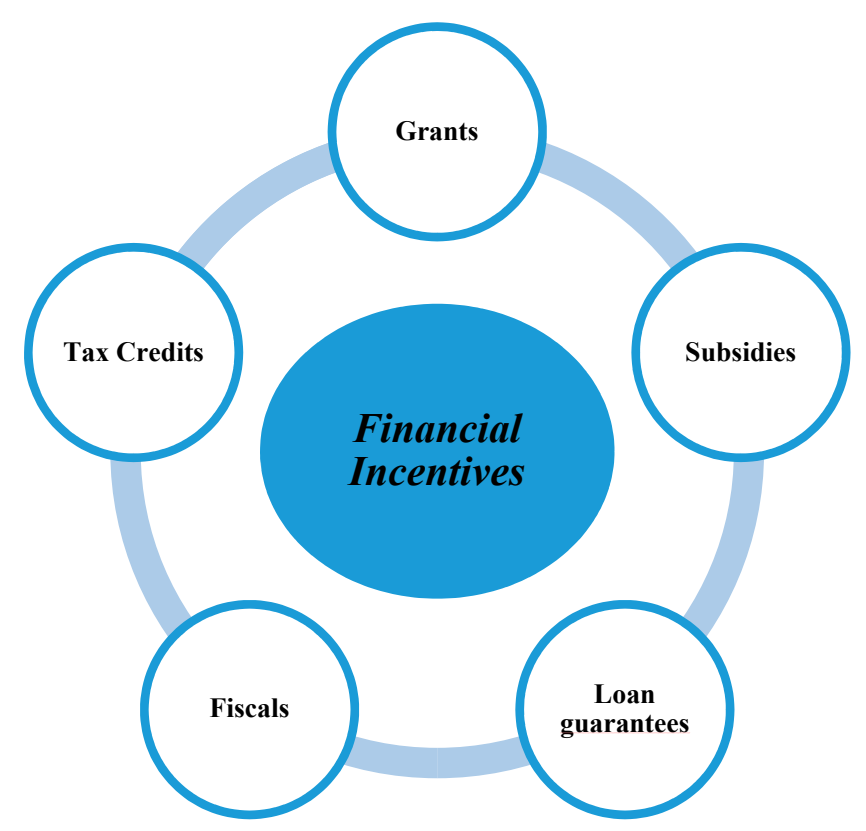

Figure 1. Main incentives to encourage private participation.

However, although the transition to a greener economy has highlighted the importance of financial innovations, these have not been fully addressed [41]. Therefore, a funding framework that includes PPPs and PF schemes is crucial in the transition toward the development of eco-innovations $[41,74,75]$. Therefore, based on this review, it is unclear if the literature includes criteria to determine the existence of any relative subordination of economic, social, or environmental sustainability elements in the structure of financing schemes, particularly on paying debt service or transforming debt into equity shares. Thus, the use of innovative financial instruments that articulate such variables will allow for the expansion of the investment in SIS influencing positively the coverage gap and sustainable development.

In this way, some researchers $[41,62,76,77]$ also indicate that not only a vast sphere of financial mechanisms could boost the development of SIS, but also that innovative financial sources for transforming the industry are required. In this way, financial mechanisms should include new models to encourage non-traditional investors by increasing incentives and creating specific markets for SIS. Thus, innovative sources of financing for infrastructure are an important area of research [78]. Regarding the financial mechanisms used for developing SIS, these could be classified into different categories by sectors as Table 4 shows. 
Table 4. Main financial mechanisms for developing Sustainable Infrastructure Systems (SIS).

\begin{tabular}{ccccc}
\hline \multicolumn{5}{c}{ Sector } \\
\hline Taxes & \multicolumn{1}{c}{ Transportation } & Building & Water/Waste & Energy \\
\hline Fees and charges & $\begin{array}{c}\text { Congestion charges } \\
\text { High Parking fees } \\
\text { Occupancy Toll Lanes }\end{array}$ & $\begin{array}{c}\text { Building permits } \\
\text { Property taxes }\end{array}$ & Tariffs and fees & Electricity user fees \\
\hline Grants & $\begin{array}{l}\text { General grants with environmental indicators, specific grants for environmental goods and } \\
\text { services, matching grants. }\end{array}$ \\
\hline PPPs & Concessions and Private Finance Initiatives (PFIs), energy performance contracts. \\
\hline Land-based income & Development charges/impact fees, tax higher density building rights. \\
\hline Loans and bonds & Loans and green bonds. \\
\hline Carbon finance & Clean Development Mechanism/Joint Implementation, voluntary carbon offsets. \\
\hline
\end{tabular}

Source: Adapted from Reference [79].

\section{Public-Private Partnerships and Project Finance to Develop Sustainable Infrastructure Systems Results}

Given that there is a recognized need to incorporate sustainability considerations in infrastructure systems [13], PPPs has become an important tool to develop sustainable and resilient infrastructure that leading to achieving 17 SDGs [3]. In order to achieve them, particularly the six (clean water and sanitation), nine (industry, innovation, and infrastructure), 11 (sustainable cities and communities), and 12 (responsible consumption and production) goals, public-private investment is necessary at all levels and in all sectors, mainly to develop social infrastructure, where the most significant gaps in coverage exist [80].

Based on an analysis of the policy fields of the implemented and empirically assessed PPPs, it is revealed that they can be attributed to sustainable development in relation to the SDGs [81] and in turn, financial sustainability of PPPs contributes to an improved (cost-) efficiency of public service delivery $[82,83]$. Thus, infrastructure systems that incorporate sustainability elements in regions with insufficient development should be implemented through PPPs [80,84].

For this, "sustainability considerations could play a significant role in all PPPs phases; even before the final decision is made to initiate an infrastructure project and procure it via PPPs, important choices will be made that affect sustainability" [13] (p. 1189). Thus, financial sustainability of PPPs can be considered important in the context under investigation [81].

The participation of the private sector through PPPs in the development of infrastructure systems is motivated by the need to improve the functioning and coverage of goods and services. Given the scarcity of public funds and restricted debt capacity, the gap between the infrastructure investments and the capacity of national budgets to fulfil this demand is widening throughout the world [85]. Thus, some countries have elected to transfer the provision of infrastructure to the private sector [86-88]. This action contributes to improving levels of quality and coverage, which have a substantial effect on economic growth and poverty reduction. The most widely applied concept related to sustainable development is known as the TBL [89]. It integrates the economic, environmental, and social dimensions. The TBL suggests that investors should devote attention not only to financial behavior, but also to the social and environmental benefits that can be obtained from a project.

Thus, both in economic and social infrastructure, sustainability is becoming increasingly important in the delivery of infrastructure projects, because stakeholders require both ethicality and economic efficiency during a project's life cycle [90]. As a consequence, when the TBL is used, the economic, social and environmental aspects of a project are better integrated [49]. Thus, PPPs offer the potential to improve sustainability dimensions; such as economic, social and environmental, they represent promising instruments in this regard. Thus, socially-minded investors are increasingly searching for innovative models for allocating financial resources to relevant initiatives in ways that maximize sustainability return on investment [53]. Therefore, elements of a "strong" sustainability perspective 
should also be included in PPPs arrangements [13]. In accordance with this, it is expected that soon in the future, public biddings will receive particular attention regarding sustainable financing so that project developers may include them within capital structure. Therefore, it is critical to analysis how PPPs could accomplish sustainability-related objectives [81].

Regarding the project management field, some authors discuss the importance of incorporating these sustainability dimensions into the practice of project management, this concern increasingly receives attention not only in procurement and PPPs literature, but also in the field of project management [13,49]. In this way, the intersection of project management and sustainability has been attracting attention from scholars and practitioners [91]. It has generated that sustainability is considered as a new school of thought in the project management area [92]. However, the contribution of PPPs to sustainability-related objectives is far from clear and it is rarely addressed in management research on PPPs [81,93].

According to Pinz et al. [81], there are two approaches to evaluating whether PPPs contribute to the achievement of sustainability-related objectives. First, using a holistic approach, scholars argue that PPPs are promising tools only if they improve the social, environmental and economic dimensions of sustainability, whereas the latter includes financial sustainability of PPPs as a, particularly important aspect. Second, according to a reductionist approach, the influence of PPPs on the accomplishment of sustainability-related objectives must be evaluated only with respect to specific sustainability dimensions.

Thus, a sound financing framework for SDGs should be based on a clear understanding of the complementary roles of public and private funding and how the two can be combined to achieve complex long-term sustainability objectives [94]. Previous work on PPPs and PF indicates also it is essential to use financial mechanisms that include public and private funds, such as PPPs based on the risk/return profile combined with grants and various other funding sources [41].

Although the first PPPs and PF guides to sustainable development were developed several years ago (in 2002), while they integrated environmental considerations into the different stages of projects [95], they did not directly include aspects related to financing. Thus, the broad field of PPPs allows for the development of complex innovations characterized by substantial uncertainty, such as eco-innovations [41]. Then, PPPs, which are innovative by nature, are fundamental for developing SIS, since they leverage private funding sources to support the provision of public utilities in order to develop a new kind of infrastructure. Additionally, PF offers real possibilities to promote sustainable development $[96,97]$. In this way, there is an enormous potential for linking public support and private finance to financial eco-innovations [98].

However, a common problem reported in economic research is that financing infrastructure systems have remained a secondary consideration [96]. Such aspects (for example, how to design financing structures) are among the main concerns of literature on PF [99]. Whereas the public sector has recognized the obvious relation between PF and sustainable development, useful tools to assist decision-makers in the integration and measurement of sustainability throughout project processes are insufficient [95]. Therefore, it is necessary to increase the current levels of investment by promoting improvements in infrastructure and assigning greater priority to the implementation of financing mechanisms linked to sustainable development for developing SIS [66].

In this way, given that sustainable development is one of the greatest global challenges of our time [13], sustainability issues should have a pivotal to prioritize investment in public infrastructures [100]. Consequently, PPPs are the potential vehicle for achieving sustainability goals [13]; thus, PPPs need to be boosting for achieving the SDGs [85].

According to Baietti et al. [101], the problem of low investment rates and a lack of financial mechanisms results from questions of how to mobilize or channel global funding resources toward sustainable projects. The main barrier to investor participation is that several technologies and projects are not financially attractive and, therefore, do not appeal to the private sector absent a certain level of support from the public sector. Whereas investments in traditional infrastructure systems have a 
well-established and organized funding framework, in contrast to sustainable infrastructure financing, which is still in early development stage.

Thus, a sound funding framework for SDGs should be based on a clear understanding of the complementary roles of public and private funding, particularly PPPs and PF schemes, and how the two can be combined to achieve complex long-term social objectives [94]. In this way, previous work on PPPs and PF indicates that, it is essential to use financial mechanisms that include public and private funds, such as PPPs based on the risk/return profile combined with grants and various other funding sources [41]. Based on this concern, the need for a new framework corresponds to a lack of research on new theories about innovations in financing strategic infrastructures and efforts to create new financing systems, as indicated in Mostafavi et al. [67]. Moreover, the scientific literature on investment and financing that addresses climate change, and therefore sustainable development, remains limited and knowledge gaps are substantial [102].

In this context, sustainability will play a strategic role in the development of infrastructure. Based on these elements, the financial framework proposed in this work, which includes the TBL's structuring process, could be considered an eco-innovative financial mechanism because, like the Paris Agreement and the SDG, it encourages the development of SIS and the private sector's involvement. According to this research, the literature contains no elements that determine whether there is any kind of subordination of TBL elements in the structuring of financing, particularly when paying debt service or transforming debt into shares. This allowed confirming the theoretical hypothesis raised in this study. For these reasons, sustainable innovation can be considered as a process that integrates environmental, social and financial sustainability factors into the business development system, generating new business models and business organization into in a funding framework.

\section{Proposed Framework}

In financing PPPs developed through PF, the scope of financial institutions is not limited to providing financial resources, and financial advising has become more important [103]. Financial institutions act as both lenders and as counsellors that provide knowledge and experience. Regarding capital structure, the debt participation represented between $65 \%$ and $90 \%$ of total investment, while the corresponding figure for typical industrial firms varied between $25 \%$ and $35 \%$ [104].

In this way, the capital structures of most PPPs developed through PF have a high degree of leverage representing debts between $90 \%$ to $70 \%$ and equity capital between $10 \%$ and $30 \%$ of total project cost [105]. Furthermore, PPPs are usually financed through a combination of capital and debt in various proportions; however, debt financing usually exceeds $70 \%$, and sometimes, it reaches $100 \%$ [106]. The trend in financing is to incorporate mezzanine-type debt into leverage structures [9,107-109], which is also called mezzanine financing. It is a form of subordinated debt, because its payments are subject to payments to senior debt holders having been satisfied; this makes it riskier than senior debt, but less risky than equity invested in by sponsors.

Thus, payment is made after the senior debt and before dividends are distributed. These resources can be provided by sponsors, institutional investors, specialized funds and even multilateral agencies and although they are used in other forms of structured finance, they have not been widely used in PF [10].

Figure 2 depicts a proposal for how mezzanine-type debt could work in this context. A sustainable financial asset is structured in a way that includes elements of both subordinated debt and convertible security, and thus, it is located between these two products. Consequently, the debt-equity conversion will be subordinated to sustainability criteria and, if present, the senior debt payment. 


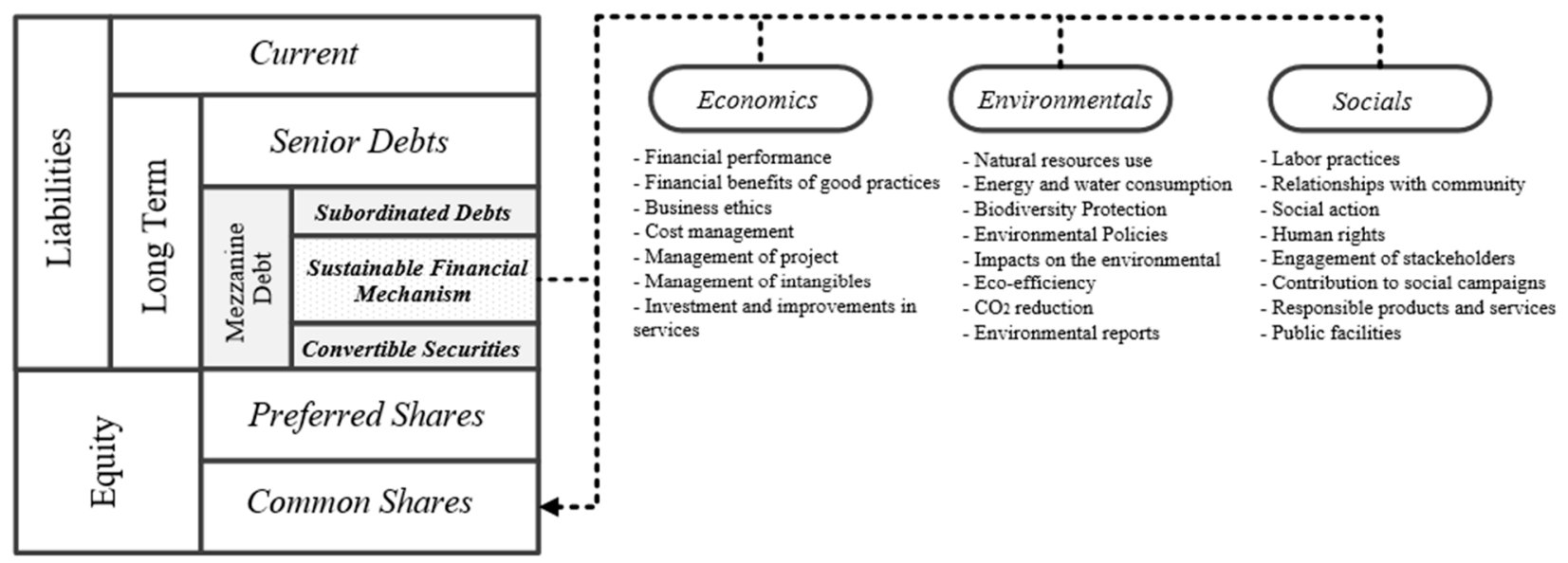

Figure 2. Proposal for mezzanine-type debt subordinated to sustainability criteria.

Regarding the criteria selection for determining sustainability in infrastructure systems, several studies [25,56,110-112] have identified rating systems, such as Engineering Environmental Quality Assessment and Award Scheme (CEEQUAL), Infrastructure Voluntary Evaluation Sustainability Tool (INVEST), Infrastructure Sustainability (IS), EnvisionTM, GreenroadsTM, for assessing sustainability in infrastructure systems. However, there are no any commonly accepted [25,49,112].

Therefore, when an SIS is financed by means of this proposal, lenders will be able to exercise this option of debt-equity conversion when the goals and covenants related to the sustainability criteria are accomplished, which must be specified in the deal. Thus, given the characteristics of mezzanine-type, lenders could be sponsors by becoming their mezzanine-type debt into equity share only if sustainable criteria are reached as Figure 2 shows. This can also be seen at the $t$ period shown in Figure 3. At this point, for example, goals and covenants have been accomplished and thus, lenders have become sponsors.

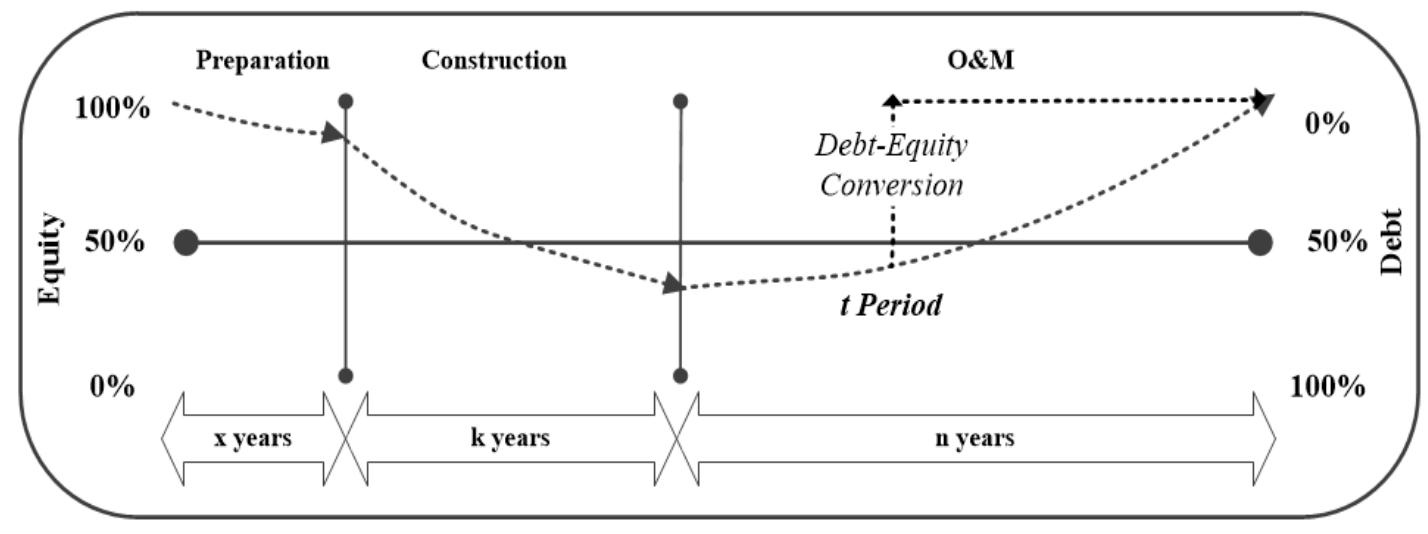

Figure 3. Capital structure's evolution.

As a consequence, the capital structure changes; it is $100 \%$ equity shares. In this way, these would have the opportunity of capturing the corporate value created by the project. Thus, the structured debt will have the characteristics of mezzanine-type debt since that could be converted into equity shares.

This approach represents an opportunity to explore and develop structured financial products that promote the diversification of funding sources and sustainable development and thus, promote the involvement of private investors. However, migrating to new forms of financing entails challenges related to the development of capital markets and the introduction of specialized investors. Successfully completing these objectives would close the coverage gap, mitigate the effects of climate change (based on reductions in $\mathrm{CO}_{2}$ emissions) and develop capital markets [112]. Therefore, it would also be possible to create a securities market indexed to SIS. 
Thus, structuring a capital market for SIS is a considerable challenge worldwide, due to the absence of a solid financing framework and the limited numbers of issuers and investors. These limitations hamper the circulation of capital and the development of investment and divestment strategies by the private sector $[54,113]$.

In general terms, infrastructure systems have traditionally been financed by sponsors and debts, using equity capital and bank loans respectively $[10,52,110]$ so, these have had a predictable capital structure [114] and have not been subordinated to sustainability criteria. According to this assumption, the capital structure varies deterministically so that it can be known at any moment. So, although capital structure has long been studied [111], little attention has been given to subordinated and convertible financial instruments and their impact on capital structure [115]. Figure 3 shows how the capital structure would evolve over time using the proposed framework.

As a result, the study of eco-innovative financing mechanisms will allow a better understanding of how sustainability criteria could be involved in the encouraging of private participation and therefore, in the financing process of SIS. The development of these mechanisms should be related to the TBL concept, which includes economic, environmental, and social dimensions. Hence, a sustainable financing strategy is critical for enhancing the development of infrastructure systems that will help to prevent dangerous climate changes, diseases due to poor service quality, coverage gaps and continuity in the service. Thus, developing a standard method that incorporates the TBL benefits is required [4]. The sustainable financial scheme proposed in this theoretical paper, which could be categorized as a financial instrument eco-innovator, examines how sustainability criteria could be incorporated into the financing process of infrastructure systems. Consequently, the creation of a sustainable financial mechanism and measure its impact on capital structure becomes one of the rarely explored topics in the traditional finance literature.

\section{Trends and Research Topics}

Research on the developments in finance related to PPPs and PF is still very limited in theory and empirical application. In order to highlight the importance of research on these subjects, academic reasons are based on the capacity to conduct research in a theoretical and business environment. The empirical evidence also indicates that there are few publications on PF, as well as corporate finance texts, including this topic. Thus, there are four different trends related to PF in the literature that allow proposing research [9]:

(1) Proposes the optimal incorporation of new projects within the investment vehicle;

(2) Conceives PF as a subset of the syndicated loan market;

(3) Addresses the relation between the use of financial contracts, business risk management, and financial decision-making; and

(4) Analyses PPPs compared to traditional public procurement mechanisms where the use of PF as a financing technique is frequently associated.

Therefore, since research on large infrastructure systems can generate an academic vision that contributes to improving the current practice, accurately identifying the effect of PF and PPPs' efficiency in the infrastructure sector offers an essential pathway for future research [116]. Furthermore, from an academic point of view, the relation among PPPs, PF, and sustainable finance have not extensively been studied and therefore, require a theory of public-private agreements. Despite the growing international importance of PF for financing large-scale projects, there is a shortage of studies in this area [117].

As discussed above, future research on sustainable finance should involve the assessment of flexibility of making sustainable projects as a strategic tool for encouraging private investment through PPPs and PF schemes, in which the private investors and the public sector develop projects that consider sustainability, accessibility, and reliability in the provision of infrastructure services [118]. These analyses should account for the sensitivity and dynamics of available financial resources. For this proposal, the real options theory would capture aspects related to the capacity of a project that 
relates to sustainable financial resources. According to the research trend in PPPs, PF, and SIS, Figure 4 summarizes the main topics (assembled by categories) present in the majority of publications, and it provides relevant ideas for the design of future research programs. This figure shows the relevance of articulating (through research projects) project management, the creation of investment vehicles, the development of financing strategies and the construction of infrastructure systems in accordance with the SDGs. Therefore, the development of financial eco-innovative mechanisms leading to promote the construction of SIS and the involvement of private investors is in accordance with the knowledge frontier in PF and PPPs.

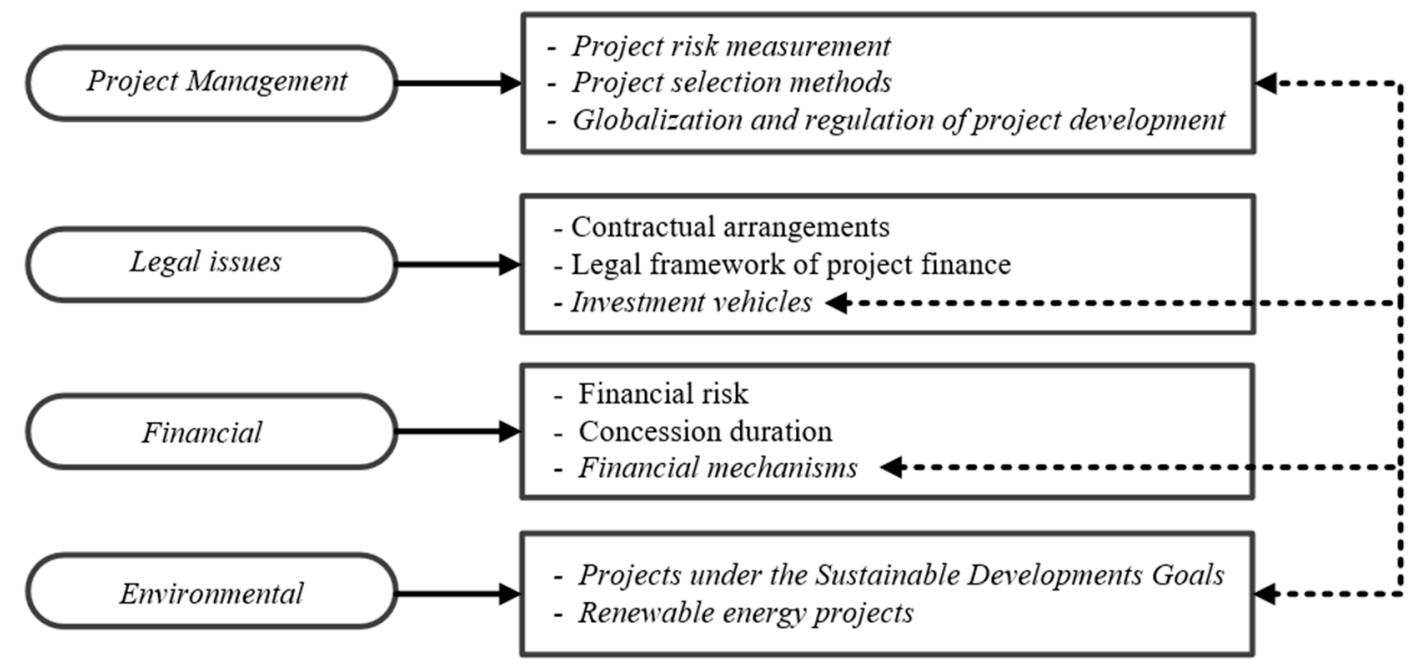

Figure 4. Topics and categories for PF and PPPs for further research focused on SIS.

\section{Conclusions}

The focus of this paper was to propose a theoretical framework based on the mezzanine-type debt mechanism for developing SIS. In this, lenders have the chance of exchanging outstanding debt for equity shares if the goals related to sustainability criteria are accomplished. This allows to lenders became sponsors and thus, the project's capital structure changes to 100\% equity shares. Doing so, lenders could capture the corporate value created by the project if any. In order to do this framework, the main relations among financial eco-innovations, PPPs, and PF for developing SIS were analyzed. Besides, this will make it possible to expand the population of investors to those who consider, in addition to financial returns, other considerations based on sustainability issues.

Finally, in order to highlight the contribution, based on the necessity of developing innovative solutions and new approaches to financing infrastructure systems, in this framework, both debt and equity are combined into a mezzanine-type debt, which incorporates sustainability criteria in the debt-equity conversion process. In this way, given that there is a need for research to construct theories related to innovations in infrastructure financing as a strategic step toward the creation of new financing systems, this financial framework could be considered as a new sustainable hybrid debt mechanism. Thus, although this framework has not been empirically tested yet, it provides the basis for linking finance and sustainability. In order to go beyond this framework, further research should validate it through case studies.

Author Contributions: J.D.G.-R. analyzed literature, conceptualized, developed the theoretical model and wrote-reviewed; S.B.-B. designed the research framework; and E.D.-G. analyzed literature, and reviewed the paper.

Funding: This research received no external funding.

Acknowledgments: The authors thank the editor and two anonymous reviewers for their useful comments allowed us to improve the quality and comprehension of the paper.

Conflicts of Interest: The authors declare no conflict of interest 


\section{References}

1. Georgoulias, A.; Vidaurre-Roche, A.-M.; Rodríguez, J. Sustainable Infrastructure in Latin America: Infrastructure $360^{\circ}$ Award. 2014. Available online: http:/ / research.gsd.harvard.edu/wpcontent/uploads / 2015/04/INF_360o_Awards_Bilingual_Publication.pdf (accessed on 3 September 2017).

2. Clark, R.; Reed, J.; Sunderland, T. Bridging funding gaps for climate and sustainable development: Pitfalls, progress and potential of private finance. Land Use Policy 2018, 71, 335-346. [CrossRef]

3. Cui, L.; Huang, Y. Exploring the Schemes for Green Climate Fund Financing: International Lessons. World Dev. 2018, 101, 173-187. [CrossRef]

4. The Johnson Foundation. Financing Sustainable Water Infrastructure. 2012. Available online: http://www. johnsonfdn.org/sites/default/files/reports_publications/WaterInfrastructure.pdf (accessed on 5 September 2018).

5. Andersen, M.M. Organising interfirm learning e as the market begins to turn Green. In Partnership and Leadership_Building Alliances for a Sustainable Future; de Bruijn, T.J.N.M., Tukker, A., Eds.; Kluwer Academic Publishers: Dordrecht, The Netherlands, 2002; pp. 103-119.

6. Arundel, A.; Kemp, R. Measuring Eco-Innovation. 2009. UNU-MERIT Working Papers (Vol. \#2009-017). Available online: http:/ / collections.unu.edu/eserv/UNU:324/wp2009-017.pdf (accessed on 5 September 2017).

7. Esty, B. Why Study Large Projects? An Introduction to Research on Project Finance. Eur. Financ. Manag. 2004, 10, 213-224. [CrossRef]

8. Farquharson, E.; de Mästle, C.T.; Yescombe, E.R.; Encinas, J. How to Engage with the Private Sector in Public-Private Partnerships in Emerging Markets, 1st ed.; World Bank: Washington, DC, USA, 2011; ISBN 978-0-8213-7863-2. [CrossRef]

9. Gatti, S. Project Finance in Theory and Practice: Designing, Structuring, and Financing Private and Public Projects. In Project Finance in Theory and Practice, 3rd ed.; Elsevier, Academic Press: London, UK, 2018; ISBN 978-0-12-39146-5.

10. Yescombe, E.R. Public-Private Partnerships: Principles of Policy and Finance; Butterworth-Heinemann: Oxford, UK, 2007; ISBN 978-0-08-048957-5.

11. Jefferies, M.; McGeorge, W. Using public-private partnerships (PPPs) to procure social infrastructure in Australia. Eng. Constr. Archit. Manag. 2009, 16, 415-437. [CrossRef]

12. González-Ruiz, J.D.; Duque, E.A.; Arango, L. Project Finance y Capital Riesgo: Aplicación en la financiación de proyectos de infraestructura. In Finanzas y Modelación; Primera, F.I., Ed.; Universidad de Medellín: Medellín, Colombia, 2014; pp. 91-119. ISBN 978-958-8815-84-8.

13. Hueskes, M.; Verhoest, K.; Block, T. Governing public-private partnerships for sustainability: An analysis of procurement and governance practices of PPP infrastructure projects. Int. J. Proj. Manag. 2017, 35, 1184-1195. [CrossRef]

14. Cui, C.; Liu, Y.; Hope, A.; Wang, J. Review of studies on the public-private partnerships (PPP) for infrastructure projects. Int. J. Proj. Manag. 2018, 36, 773-794. [CrossRef]

15. Wilson, $\mathrm{C}$. Why should sustainable finance be given priority? Lessons from pollution and biodiversity degradation. Account. Res. J. 2010, 23, 267-280. [CrossRef]

16. Schumpeter, J. Capitalism, Socialism and Democracy; Harper Row: New York, NY, USA, 1942.

17. Karakaya, E.; Hidalgo, A.; Nuur, C. Diffusion of eco-innovations: A review. Renew. Sustain. Energy Rev. 2014, 33, 392-399. [CrossRef]

18. Mostafavi, A.; Abraham, D.; DeLaurentis, D. Toward Sustainable Financial Innovation Policies in Infrastructure: A Framework for Ex-Ante Analysis. Comput. Civ. Eng. 2011, 41-50. [CrossRef]

19. Tan, Y.; Shen, L.; Yao, H. Sustainable construction practice and contractors' competitiveness: A preliminary study. Habitat Int. 2011. [CrossRef]

20. Wu, G.; Qiang, G.; Zuo, J.; Zhao, X.; Chang, R. What are the Key Indicators of Mega Sustainable Construction Projects?-A Stakeholder-Network Perspective. Sustainability 2018, 10, 2939. [CrossRef]

21. Zhang, X. Financial Viability Analysis and Capital Structure Optimization in Privatized Public Infrastructure Projects. J. Constr. Eng. Manag. 2005, 131, 656-668. [CrossRef]

22. Boons, F.; Wagner, M. Assessing the relationship between economic and ecological performance: Distinguishing system levels and the role of innovation. Ecol. Econ. 2009, 68, 1908-1914. [CrossRef] 
23. Przychodzen, J.; Przychodzen, W. Relationships between eco-innovation and financial performance-Evidence from publicly traded companies in Poland and Hungary. J. Clean. Prod. 2015, 90, 253-263. [CrossRef]

24. Waltman, L. A review of the literature on citation impact indicators. J. Informetr. 2016, 10, 365-391. [CrossRef]

25. Krajangsri, T.; Pongpeng, J. Effect of Sustainable Infrastructure Assessments on Construction Project Success Using Structural Equation Modeling. J. Manag. Eng. 2016, 33, 1-12. [CrossRef]

26. Egler, H.-P.; Frazao, R. Sustainable Infrastructure and Finance-How to Contribute to a Sustainable Future. 2016. Available online: http:/ / unepinquiry.org/wp-content/uploads/2016/06/Sustainable_Infrastructure_ and_Finance.pdf (accessed on 10 October 2017).

27. Mostafavi, A.; Abraham, D.; Mannering, F.; Vives, A.; Valentin, V. Assessment of Public Perceptions of Innovative Financing for Infrastructure. Constr. Res. Congr. 2012, 2260-2269. [CrossRef]

28. Fabozzi, F.J. Accessing Capital Markets through Securitization; Wiley: Oxford, UK, 2001; ISBN 978-1-883-24992-2.

29. Blanch, J. Financial Innovations and their role in the modern financial systems-Identitication and systematization of the problem. Financ. Internet Q. e-Finanse 2011, 7, 13-26. Available online: http: / / hdl.handle.net/10419/66758 (accessed on 3 September 2017).

30. Dalberg. Innovative Financing for Development: Scalable Business Models that Produce Economic, Social, and Environmental. 2014. Available online: http:/ /globaldevincubator.org/wp-content/uploads/2014/09/ Innovative-Financing-for-Development.pdf (accessed on 3 September 2017).

31. Ozusaglam, S. Environmental innovation: A concise review of the literature. Vie Sci. l'entreprise 2012, 191-192, 15. [CrossRef]

32. Cui, Y.; Geobey, S.; Weber, O.; Lin, H. The Impact of Green Lending on Credit Risk in China. Sustainability 2018, 10, 2008. [CrossRef]

33. Faber, A.; Frenken, K. Models in evolutionary economics and environmental policy: Towards an evolutionary environmental economics. Technol. Forecast. Soc. Chang. 2009, 76, 462-470. [CrossRef]

34. Carrillo-Hermosilla, J.; del Río, P.; Könnölä, T. Diversity of eco-innovations: Reflections from selected case studies. J. Clean. Prod. 2010, 18, 1073-1083. [CrossRef]

35. Hojnik, J.; Ruzzier, M. What drives eco-innovation? A review of an emerging literature. Environ. Innov. Soc. Transit. 2016, 19, 31-41. [CrossRef]

36. Schiederig, T.; Tietze, F.; Herstatt, C. Green innovation in technology and innovation management-An exploratory literature review. RED Manag. 2012, 42, 180-192. [CrossRef]

37. Rennings, K. Redefining innovation-Eco-innovation research and the contribution from ecological economics. Ecol. Econ. 2000, 32, 319-332. [CrossRef]

38. Little, A.D. How Leading Companies Are Using Sustainability-Driven Innovation to Win Tomorrow's Customers; World Business Council for Sustainab le Development (WBCSD): Geneva, Switzerland, 2005.

39. Porter, M.E.; van der Linde, C. Toward a New Conception of the Environment-Competitiveness Relationship. J. Econ. Perspect. 1995, 9, 97-118. [CrossRef]

40. Yang, F.; Yang, M. Analysis on China's eco-innovations: Regulation context, intertemporal change and regional differences. Eur. J. Oper. Res. 2015, 247, 1003-1012. [CrossRef]

41. Polzin, F.; von Flotow, P.; Klerkx, L. Addressing barriers to eco-innovation: Exploring the finance mobilisation functions of institutional innovation intermediaries. Technol. Forecast. Soc. Chang. 2016, 103, 34-46. [CrossRef]

42. King, A.A.; Lenox, M.J. Does It Really Pay to Be Green? An Empirical Study of Firm Environmental and Financial Performance. J. Ind. Ecol. 2001, 5, 105-116. Available online: http:/ / mitpress.mit.edu/JIE (accessed on 5 September 2017). [CrossRef]

43. Renneboog, L.; Ter, J.; Zhang, C. Socially responsible investments: Institutional aspects, performance, and investor behavior. J. Bank. Financ. 2008, 32, 1723-1742. [CrossRef]

44. Linnenluecke, M.K.; Chen, X.; Ling, X.; Smith, T.; Zhu, Y. Emerging trends in Asia-Pacific finance research: A review of recent influential publications and a research agenda. Pac. Basin Financ. J. 2016, 36, 66-76. [CrossRef]

45. Clarkson, P.M.; Li, Y.; Richardson, G.D.; Vasvari, F.P. Does it really pay to be green? Determinants and consequences of proactive environmental strategies. J. Account. Public Policy 2011, 30, 122-144. [CrossRef]

46. Govindan, K.; Diabat, A.; Madan, K. Analyzing the drivers of green manufacturing with fuzzy approach. J. Clean. Prod. 2015, 96, 182-193. [CrossRef]

47. Bolton, B. Sustainable Financial Invesment. Maximizing Corporate Profits and Long-Term Economic Value Creation, 1st ed.; Palgrave Macmillan: New York, NY, USA, 2015; ISBN 978-1-137-41199-0. 
48. Fatemi, A.M.; Fooladi, I.J. Sustainable finance: A new paradigm. Glob. Financ. J. 2013, 24, 101-113. [CrossRef]

49. Martens, M.L.; Carvalho, M.M. Key factors of sustainability in project management context: A survey exploring the project managers' perspective. Int. J. Proj. Manag. 2016, 2016, 1-19. [CrossRef]

50. Meltzer, J.P. Financing Low Carbon, Climate Resilient in Frastructure: The Role of Climate Finance and Green Financial Systems. 2016. Available online: https:/ / ssrn.com/abstract=2841918 (accessed on 26 November 2018). [CrossRef]

51. Elkington, J. Cannibals with Forks: The Triple Bottom Line of 21st Century Business, 6th ed.; New Society Publishers: Gabriola, BC, Canada, 1998.

52. Foxon, T.J.; Bale, C.S.E.; Busch, J.; Bush, R.; Hall, S.; Roelich, K. Low carbon infrastructure investment: Extending business models for sustainability. Infrastruct. Complex. 2015, 2, 4. [CrossRef]

53. Rizzi, F.; Pellegrini, C.; Battaglia, M. The structuring of social finance: Emerging approaches for supporting environmentally and socially impactful projects. J. Clean. Prod. 2018, 170, 805-817. [CrossRef]

54. Kivleniece, I.; Quelin, B.V. Creating and Capturing Value in Public-Private Ties: A Private Actor's Perspective. Acad. Manag. Rev. 2012, 37, 272-299. [CrossRef]

55. Laszlo, C. The Sustainable Company: How to Create Lasting Value through Social and Environmental Performance; Island Press: Washington, DC, USA, 2003.

56. Gupta, R.; Morris, J.W.F.; Espinoza, D. Financial Sustainability as a Metric for Infrastructure Projects. In Proceedings of the Geo-Chicago 2016, Chicago, IL, USA, 14-18 August 2016; pp. 653-662. [CrossRef]

57. González-Ruiz, J.D.; Arboleda, C.; Botero, S. A Proposal for Green Financing as a Mechanism to Increase Private Participation in Resilient Water Infrastructure Systems: The Colombian Case. Procedia Eng. 2016, 145, 180-187. [CrossRef]

58. Gollier, C. Pricing the Planet's Future: The Economics of Discounting in an Uncertain World; Princeton University Press: Princeton, NJ, USA, 2013; Available online: https:/ / press.princeton.edu/titles/9894.html (accessed on 5 September 2017).

59. García, E. Los Instrumentos Financieros Innovadores, una Alternativa Eficaz Combatir para el Cambio Climático-Noticias I iAgua. 2016. Available online: https://www.iagua.es/noticias/caf/16/09/23/ instrumentos-financieros-innovadores-alternativa-eficaz-combatir-cambio (accessed on 10 October 2017).

60. Kern, F.; Gaede, J.; Meadowcroft, J.; Watson, J. The political economy of carbon capture and storage: An analysis of two demonstration projects. Technol. Forecast. Soc. Chang. 2016, 102, 250-260. [CrossRef]

61. Gherghina, Ş.; Onofrei, M.; Vintilă, G.; Armeanu, D. Empirical Evidence from EU-28 Countries on Resilient Transport Infrastructure Systems and Sustainable Economic Growth. Sustainability 2018, 10, 2900. [CrossRef]

62. Marcus, A.; Malen, J.; Ellis, S. The Promise and Pitfalls of Venture Capital as an Asset Class for Clean Energy Investment: Research Questions for Organization and Natural Environment Scholars. Organ. Environ. 2013, 26, 31-60. [CrossRef]

63. González-Ruiz, J.D.; Rojas, M.; Arboleda, C.; Botero, S. Project Finance y Asociaciones Público-Privada para la provisión de servicios de infraestructura en Colombia Introducción. Obras y Proy. 2014, 16, 61-82. [CrossRef]

64. Foxon, T.; Pearson, P. Overcoming barriers to innovation and diffusion of cleaner technologies: Some features of a sustainable innovation policy regime. J. Clean. Prod. 2008, 16, S148-S161. [CrossRef]

65. Czarnitzki, D.; Hanel, P.; Rosa, J.M. Evaluating the impact of R\&D tax credits on innovation: A microeconometric study on Canadian firms. Res. Policy 2011, 40, 217-229. [CrossRef]

66. Barbero, J.; Forteza, J.H.; Skerk, C.; Mejía, A.; Katz, R.; García, R.; Gómez, M. IDEAL 2014. La Infraestructura en el Desarrollo de América Latina (Main Document); CAF: Bogotá DC, Colombia, 2015; Available online: http:/ / scioteca.caf.com/handle/123456789/746 (accessed on 7 October 2017).

67. Mostafavi, A.; Abraham, D.; Vives, A. Exploratory analysis of public perceptions of innovative financing for infrastructure systems in the U.S. Transp. Res. Part A Policy Pract. 2014, 70, 10-23. [CrossRef]

68. Weber, K.M.; Rohracher, H. Legitimizing research, technology and innovation policies for transformative change: Combining insights from innovation systems and multi-level perspective in a comprehensive 'failures' framework. Res. Policy 2012, 41, 1037-1047. [CrossRef]

69. Haley, U.C.V.; Schuler, D.A. Government policy and firm strategy in the solar photovoltaic industry. Calif. Manag. Rev. 2011, 54, 17-38. [CrossRef] 
70. Hendry, C.; Harborne, P.; Brown, J. So what do innovating companies really get from publicly funded demonstration projects and trials? innovation lessons from solar photovoltaics and wind. Energy Policy 2010, 38, 4507-4519. [CrossRef]

71. Pauw, W.P. Not a panacea: Private-sector engagement in adaptation and adaptation finance in developing countries. Clim. Policy 2015, 15, 583-603. [CrossRef]

72. Lee, S.; Lee, B.; Kim, J.; Kim, J. A financing model to solve financial barriers for implementing green building projects. Sci. World J. 2013, 2013. [CrossRef] [PubMed]

73. Ozorhon, B. Analysis of Construction Innovation Process at Project Level. J. Manag. Eng. 2013, 29 , 455-463. [CrossRef]

74. Leete, S.; Xu, J.; Wheeler, D. Investment barriers and incentives for marine renewable energy in the UK: An analysis of investor preferences. Energy Policy 2013, 60, 866-875. [CrossRef]

75. Moore, M.-L.; Westley, F.R.; Nicholls, A. The Social Finance and Social Innovation Nexus. J. Soc. Entrep. 2012, 3, 115-132. [CrossRef]

76. Bielenberg, A.; Kerlin, M.; Oppenheim, J.; Roberts, M. Financing Change: How to Mobilize Private-Sector Financing for Sustainable Infrastructure; Mckinsey \& Company: Washington, DC, USA, 2016; Available online: http://newclimateeconomy.report/2015/wp-content/uploads/sites/3/2016/01/Financing change_How_to_mobilize_private-sector_financing_for_sustainable-_infrastructure.pdf (accessed on 3 September 2017).

77. Mostafavi, A.; Abraham, D.M.; Sinfield, J.V. Innovation in Infrastructure Project Finance: A Typology for Conceptualization. Int. J. Innov. Sci. 2014, 6, 127-144. [CrossRef]

78. Kumari, A.; Sharma, A.K. Infrastructure financing and development: A bibliometric review. Int. J. Crit. Infrastruct. Prot. 2017, 16, 49-65. [CrossRef]

79. Merk, O.; Saussier, S.; Staropoli, C.; Slack, E.; Kim, J. Financing Green Urban Infrastructure; OECD Publishing: Paris, France, 2012. [CrossRef]

80. González-Ruiz, J.D.; Arboleda, C.A.; Botero, S. Financiación de Proyectos de Infraestructura Sostenible Bajo Asociaciones Público-Privadas: Caso Colombia. Red Iberoamericana de Ingeniería de Proyectos. Available online: https: / / scielo.conicyt.cl/scielo.php?pid=S0718-28132016000200005\&script=sci_arttext (accessed on 26 November 2017).

81. Pinz, A.; Roudyani, N.; Thaler, J. Public-private partnerships as instruments to achieve sustainability-related objectives: The state of the art and a research agenda. Public Manag. Rev. 2017, 20, 1-22. [CrossRef]

82. Pérez-López, G.; Prior, D.; Zafra-Gómez, J.L. Rethinking New Public Management Delivery Forms and Efficiency: Long-Term Effects in Spanish Local Government: Table 1. J. Public Adm. Res. Theory 2015, 25, 1157-1183. [CrossRef]

83. Teicher, J.; Alam, Q.; van Gramberg, B. Managing trust and relationships in PPPs: Some Australian experiences. Exp. Int. Rev. Adm. Sci. 2006, 72, 85-100. [CrossRef]

84. Ponomarenko, T.V.; Cherepovitsyn, A.E.; Fedoseev, S.V.; Sidorov, D.E. Organizational-Economic Mechanism of Financing Strategic Investment Projects at the Regional Level in Regions with Poor Infrastructure. Int. J. Appl. Eng. Res. 2016, 11, 9007-9013.

85. Anwar, B.; Xiao, Z.; Akter, S.; Rehman, R.-U. Sustainable Urbanization and Development Goals Strategy through Public-Private Partnerships in a South-Asian Metropolis. Sustainability 2017, 9, 1940. [CrossRef]

86. Alonso-Conde, A.B.; Brown, C.; Rojo-Suarez, J. Public private partnerships: Incentives, risk transfer and real options. Rev. Financ. Econ. 2007, 16, 335-349. [CrossRef]

87. Jin, X.-H.; Zhang, G. Modelling optimal risk allocation in PP projects using artificial neural networks. Int. J. Proj. Manag. 2011, 29, 591-603. [CrossRef]

88. Zhang, Z.; Durango-Cohen, P. A strategic model of public-private partnerships in transportation: Effect of taxes and cost structure on investment viability. Res. Transp. Econ. 2012, 36, 9-18. [CrossRef]

89. Carvalho, M.M.; Rabechini, R., Jr. Fundamentos em Gestão de Projetos: Construindo competências para gerenciar projetos: Teoria e Casos, 3rd ed.; Atlas: São Paulo, Spain, 2011; Available online: http:/ /www.grupogen.com. br/fundamentos-gestao-projetos-23393 (accessed on 12 September 2017).

90. Kivilä, J.; Martinsuo, M.; Vuorinen, L. Sustainable project management through project control in infrastructure projects. Int. J. Proj. Manag. 2017, 35, 1167-1183. [CrossRef]

91. Silvius, A.J.G.; Schipper, R.; Nedeski, S. Sustainability in project management: Reality bites 1. PM World J. 2013, 2, 1-14. 
92. Silvius, G. Sustainability as a new school of thought in project management. J. Clean. Prod. 2017, 166, 1479-1493. [CrossRef]

93. Dellas, E. CSD water partnerships: Privatization, participation and legitimacy. Ecol. Econ. 2011, 70, $1916-1923$. [CrossRef]

94. Schmidt-Traub, G.; Sachs, J.D. Financing Sustainable Development: Implementing the SDGs through Effective Investment Strategies and Partnerships; Sustainable Development Solution Network Working Paper. 2015. Available online: http://Unsdsn.Org/Wp-Content/Uploads/2015/04/150619-SDSN-FinancingSustainable-Development-Paper-FINAL-02.Pdf (accessed on 5 September 2017).

95. Zhou, L.; Keivani, R.; Kurul, E. Sustainability performance measurement framework for PFI projects in the UK. J. Financ. Manag. Prop. Constr. 2013, 18, 232-250. [CrossRef]

96. Estache, A.; Serebrisky, T.; Wren-Lewis, L. Financing infrastructure in developing countries. Oxf. Rev. Econ. Policy 2015, 31, 279-304. [CrossRef]

97. Shan, M.; Hwang, B.-G.; Zhu, L. A Global Review of Sustainable Construction Project Financing: Policies, Practices, and Research Efforts. Sustainability 2017, 9, 2347. [CrossRef]

98. Mowery, D.C.; Nelson, R.R.; Martin, B.R. Technology policy and global warming: Why new policy models are needed (or why putting new wine in old bottles won't work). Res. Policy 2010, 39, 1011-1023. [CrossRef]

99. Gatti, S. Project Finance in Theory and Practice: Designing, Structuring, and Financing Private and Public Projects, 3rd ed.; Elsevier: London, UK, 2018.

100. Pardo-Bosch, F.; Aguado, A. Sustainability as the key to prioritize investments in public infrastructures. Environ. Impact Assess. Rev. 2016, 60, 40-51. [CrossRef]

101. Baietti, A.; Shlyakhtenko, A.; la Rocca, R.; Patel, U.D. Green Infrastructure Finance: Leading Initiatives and Research; World Bank: Washington, DC, USA, 2012; Available online: https:/ / openknowledge.worldbank. org/handle/10986/13142 (accessed on 4 May 2017).

102. Gouldson, A.; Kerr, N.; Millward-Hopkins, J.; Freeman, M.C.; Topi, C.; Sullivan, R. Innovative financing models for low carbon transitions: Exploring the case for revolving funds for domestic energy efficiency programmes. Energy Policy 2015, 86, 739-748. [CrossRef]

103. González, J. La financiación de la colaboración público-privada: El «Project Finance». Presup. y Gasto Público 2006, 45, 175-185. Available online: http://www.ief.es/documentos/recursos/publicaciones/revistas / presu_gasto_publico/45_Financiacion.pdf (accessed on 5 May 2017).

104. Esty, B. Big Deals: Financing Large-Scale Investments; Working Knowledge A Report Resarch; Harvard Business School: Boston, MA, USA, 2000; Volume IV, Available online: http://hbswk.hbs.edu/item/1690.html (accessed on 4 May 2017).

105. Kwak, Y.H.; Chih, Y.; Ibbs, C.W. Towards a Comprehensive Understanding of Public Private Partnerships for Infrastructure Development. Calif. Manag. Rev. 2009, 51, 51-78. [CrossRef]

106. Akintoye, A.; Beck, M. Policy, Finance \& Management for Public-Private Partnerships, 1st ed.; Wiley-Blackwell: Oxford, UK, 2009.

107. Croce, R.; Gatti, S. Financing infrastructure-International trends. OECD J. Financ. Mark. Trends 2014, 2014, 123-138. [CrossRef]

108. Nijs, L. Mezzanine Financing-Tools, Applications and Total Performance; Wiley Finance: West Sussex, UK, 2014; ISBN 978-1-118-76520-3.

109. Mascareñas, J. Fusiones, Adquisiciones y Valoración de Empresas, 5st ed.; Ecobook: Madrid, Spain, 2011; ISBN 978-84-96877-45-0.

110. Fernández-Sánchez, G.; Rodríguez-López, F. A methodology to identify sustainability indicators in construction project management-Application to infrastructure projects in Spain. Ecol. Indic. 2010, 10, 1193-1201. [CrossRef]

111. Poveda, C.A.; Lipsett, M. A Review of Sustainability Assessment and Sustainability/Environmental Rating Systems and Credit Weighting Tools. J. Sustain. Dev. 2011, 4, 36. [CrossRef]

112. Rodríguez, F.; Fernández, G. Challenges for Sustainability Assessment by Indicators. Leadersh. Manag. Eng. 2011, 11, 321-325. [CrossRef]

113. Barbero, J. La Infraestructura en el Desarrollo integral de América Latina. Diagnóstico Estratégico y Propuestas para una Agenda Prioritaria; CAF: Bogotá, Colombia, 2011; Volume 132. 
114. Modigliani, M.; Miller, M. The Cost of Capital, Corporation Finance and The Theory of Investment. Am. Econ. Rev. 1958, 48, 261-297. Available online: https://doi.org/http://www.jstor.org/stable/1809766 (accessed on 3 September 2017).

115. Dong, F.; Chiara, N.; Kokkaew, N.; Wu, J. Stochastic Optimization of Capital Structure in Privately Funded Infrastructure Projects. J. Priv. Equity 2011, 15, 36-47. [CrossRef]

116. Kleimeier, S.; Versteeg, R. Project finance as a driver of economic growth in low-income countries. Rev. Financ. Econ. 2010, 19, 49-59. [CrossRef]

117. Girardone, C.; Snaith, S. Project finance loan spreads and disaggregated political risk. Appl. Financ. Econ. 2011, 21, 1725-1734. [CrossRef]

118. Duque, E.A.; González, J.D.; Restrepo, J.C. Developing Sustainable Infrastructure for Small Hydro Power Plants through Clean Development Mechanisms in Colombia. Procedia Eng. 2016, 145, 224-233. [CrossRef]

2018 by the authors. Licensee MDPI, Basel, Switzerland. This article is an open access article distributed under the terms and conditions of the Creative Commons Attribution (CC BY) license (http://creativecommons.org/licenses/by/4.0/). 